Est $\mathrm{Ag} 47$ (2012) 37-56

\title{
How to Relate Theology and Science Today: Challenges and Opportunities
}

\author{
MiKAEL STENMARK \\ Decano de la Facultad de Teología \\ Universidad de Uppsala
}

ABSTRACT: Science and theology apparently compete in the same terrain. Beyond this broadly shared opinion, it is convenient to analyze the kind of 'job' each of these instances assumes. Science pursues epistemic goals, while religion follows soteriological and moral ones. Such a distinction allows for a better insight into the possible ways to relate to each other: competition, independence and contact, become the standard positions. The contact view appears as more fitting for the current theological program. The case of human uniqueness in the context of evolutionary theory exemplifies the challenges born from that position. This strategy finds four expressions on its own: the conservative, the traditional, the liberal, and the constructivist.

KEY WORDS: Science, theology, relation, competition, independence, contac.

RESUMEN: La ciencia y la teología compiten aparentemente en el mismo terreno. Más allá de esta opinión ampliamente compartida, es conveniente analizar el tipo de "trabajo" que, cada una de ellas, asume. La ciencia persigue objetivos "epistémicos", mientras que la religión los persigue "soteriológicos" y "morales". Esta distinción permite una mejor comprensión de las posibles formas de relacionarse una con otra: la competencia, la independencia y el contacto, se convierten en posiciones comunes. La idea del contacto aparece como la más apropiada para el programa teológico actual. El caso de la singularidad humana en el contexto de la teoría evolutiva es un ejemplo de los desafíos que nacen de esa posición. Esta estrategia encuentra cuatro expresiones propias: la conservadora, la tradicional, la liberal y la constructivista.

PALABRAS CLAVE: Ciencia, teología, relación, competición, independencia, contacto. 
The number of academic books and articles, written during the last 20 years on the relationship between science and religion is truly amazing, and new ones are coming out almost every day. And this is true about the media as well: One day we can read that scientists have discovered a God gene or that science has shown that it is natural to believe in God and unnatural to be an atheist. Another day we can read that science has disproved the existence of God, shown that God has not created the world, and that most top scientists are atheists or at least agnostics.

It is hard to know what to believe on these matters both for scholars and people in general. How should one think about the relationship science and theology (or Christian faith) today? That will be the topic of my lecture.

I suggest that we follow Mary Midgley and ask this question: What kind of job is it that science and religion do? Midgley writes:

"It is, of course, quite widely believed that science and religion are in conflict. Many people, indeed, suppose that this battle has already been wonthat science has in some sense 'disproved' religion, and reigns instead of it. This is an extremely odd idea, since it has to mean that they have somewhere been competing for the same job, and it is not obvious what that job might be" (Midgley 1992, 51).

So if we want to compare and understand the relationship between science and religion, or more specifically between science and Christian faith, it seems to be a very reasonable strategy to take into account what kind of job these highly influential enterprises of human life might do. So what kind of job is it that science and Christian faith do for people who participate in these activities?

I suggest that we analyze the kind of job science and Christian faith (or religion more generally speaking) do in terms of the purpose or the goals of these two practices and the means that their practitioners have developed to achieve these goals.

Once we have a good grip on this we are in a position to assess whether the two compete for the same job (the competition view), or do completely different jobs (the independent view), or do jobs that overlap to some extent (the contact view). So I think that there are three basic views we can identify when it comes to the science-religion relationship:

- the competition view

- the independent view

- the contact view 


\section{The Goals of Science and Christianity}

So let us focus on the goals of science and Christianity, but let us do it against the background of our human situation. It is important to take into account that religion and science do not exist in a vacuum. Instead, they are practiced and valued by human beings with limited resources who, because of their constitution and environment, have certain needs. For instance, things happen to us that we do not anticipate and that sometimes threaten our lives and wellbeing. We need things that are not always easy to obtain, such as nutritious food, medicine, houses, bridges, and vehicles. In dealing with these things science has proved to be of great value. It enables us to control nature, and when we cannot control it, at least to predict it, or to adjust our behavior to an uncooperative world. We can say that science has a technological goal and we value science because it is useful and because it helps us control, predict, and alter the world. However, many scientists themselves think that science also has another goal, namely to theoretically understand the natural and social world or to obtain knowledge or at least justified belief about these states of affairs. Science not only has a technological goal but also an epistemic goal.

But we do not have to satisfy merely material needs to be alive and well. We also have to give attention to spiritual or existential needs. Our wellbeing thus depends upon our ability to deal with our experiences of suffering, death, guilt, or meaninglessness (existential concerns) and we also need to know what is good for us, what we ought to strive towards and how we should treat others (moral concerns). In dealing with these phenomena, religion has proved to be of great value. We can say that religion has a soteriological goal and also a moral goal.

So if we turn to Christianity; it is a practice which wants to help people realize that they are sinners in need of God's forgiveness and renewal, and give guidance to how they should live a good life in relationship to other humans and to God. The job Christians have taken on themselves is to help people understand that God loves us and therefore wants to have something to do with us, but also that God expects certain things from us in return.

Stephen Wykstra expresses such a view when he writes that,

Sometimes, when our lives cry out for redemptive change, what is important is not precise predictions, but the disclosure of unanticipated new meanings where old ones have been shattered. Demanding that religious discourse here provide precise predictions would be obtuse. Sometimes we find our 
lives in pits where what we most need to be delivered from is our way of taking things in our own hands. (Wykstra 1990: 137)

Christianity (and perhaps all other religions) thus contains at least: (a) a diagnosis of what the basic problem of human life is, (b) an understanding of what ideal human flourishing or "spiritual health" amounts to, and (c) an ordination of how this basic problem could be solved, how salvation could be obtained or what is a cure to our "spiritual illness." Religions differ insofar as their diagnoses, ideals of human flourishing, and ordinations differ.

\section{THE INDEPENDENT ViEW}

This analysis seems to suggest that there is good reason to embrace the independent view. Science and Christianity do different jobs, and therefore there is no overlap between the two practices or any competition between them. But we need them both to be able to satisfy our needs. Holmes Rolston maintains that "science is never the end of the story, because science cannot teach humans what they most need to know: the meaning of life and how to value it" (Rolston 1999, 161-62). Steven Jay Gould thinks that we should use this model to understand science's relationship to all religions. He writes that "the net, or magisterium, of science covers the empirical realm: what is the universe made of (fact) and why does it work this way (theory). The magisterium of religion extends over questions of ultimate meaning and moral value. These two magisteria do not overlap, nor do they encompass all inquiry ..." (Gould 1999, 6). There are two jurisdictions and each party should keep off the other's turf.

\section{A Response}

One way to respond to the claim that the independent view is the best way to understand the relationship between science and Christianity, is to point out that these elements (a), (b), and (c) of religion we have identified entail assumptions about what exists. A religion like Christianity therefore contains also:

(d) beliefs about the constitution of reality, that is, at least those beliefs that must be true for the diagnosis to be correct and for the ordination to work and for a realization of ideal human flourishing to be possible. 
According to Christian faith, our problem is that although we have been created in the image of God we have sinned against God and the cure is that God, through Jesus Christ, provides forgiveness and restoration. But for this cure to work it appears that at least it must be true that God exists, that Jesus Christ is the son of God, that we are created in the image of God, that God is a creator, that God wants to forgive us, and that God is loving us. Hence it seems as if Christianity, and not only science, would have an epistemic goal, that is, it attempts to say something true about reality. If so, a religious practice like Christianity is meant to tell us something true about who God is, what God's intentions are, what God has done, what God values, and how we fit in when it comes to these intentions, actions, and values.

But I would like stress that this epistemic goal is subordinated to the soteriological goal. The soteriological goal shapes the epistemic goal of Christianity. This is true, at least, in the sense that many Christians do not merely affirm the truth of beliefs such as that there is a God, that God is love, or that God created the world. Instead their primary aim is to have an appropriate relation to God so that they can implement the divine dimension of reality in their lives. Many Christians believe that God's revelation, although it is incomplete, gives knowledge that is adequate for believers' needs. For them it is sufficient to know what is necessary for them to live the life they must in relation to God. These believers aim at significant or important truths, truths that are useful for them in their relation to God.

Scientists have the epistemic goal of contributing to the long-term community project of understanding the natural and social world. In a similar fashion Christians may have the aim of contributing to the religious community's long-term goal of understanding God, to the extent that this is understood to be possible for beings in our predicament. Note that even though this formulation parallels that of science, it is, I think, a more controversial and slightly misleading characterization in the religious case. I suggest that this is because in Christianity, the emphasis is so much on being Christian, on living a life in the presence of God. The epistemic goal of Christian faith is shaped by the soteriological agenda. Therefore, it is perhaps more adequate to say that the epistemic goal of Christianity is to promote as much knowledge of God as is necessary for people to live a religious life successfully (knowing that God is love, that God wants to redeem us and how God redeems us, etc.).

A crucial difference, then, between the epistemic goal of Christianity and science is that in science the aim is to increase the general body of knowledge about the social and natural world, whereas in Christianity it is to increase the knowledge of each of its believers to such an extent that 
they can live a religious life successfully. To contribute to the epistemic goal of Christianity is first of all to increase, up to a certain level, the religious knowledge (say, at least to the level necessary for salvation) of as many people as possible. It is not, as in science, to move the frontiers of knowledge of nature and society forward as much as possible.

\section{Means}

To achieve their epistemic goal, scientists work on different problems. They specialize and there is thus a division of labor. Moreover, scientists try to provide individuals, belonging to different research groups, with access to the data they discover and to the theories they develop. An integrated part of this process is not only co-operation, but also competition among scientists, allowing and encouraging the critical scrutiny of other people's work, thus being aware that one's own work will probably receive the same treatment. Therefore scientists try to make certain that it will stand up to such an evaluation.

In religion, on the other hand, the process of critical evaluation is done in quite a different and less systematic way. The key question in this practice is whether the means (or in scientific terminology, the methods) that have been developed by the previous generations of Christians are still appropriate to allow contact with God, to enable its practitioners to live a Christian life successfully and to help other people become Christians. If not, these means need to be improved or even radically changed in some way.

\section{An Objection}

Let us, with this in mind, go back to the evaluation of the independent view. Its proponents could still respond by saying that even if both science and Christianity have epistemic goals, they intend to tell us the truth about different things or about different aspects of reality, and therefore no contact is possible between these truth claims.

\section{A Response}

One problem with this response is that we cannot a priori (or beforehand) know that no contact is possible but have to investigate it. Furthermore, we seem to be able identify cases where such contact actually takes place. For instance, the traditional Judeo-Christian view held that the first human be- 
ings, Adam and Eve, were created in the Garden of Eden. But evolutionary theory undermines the idea that there was a paradise without conflict, death, and suffering, and says that we are the descendants of earlier, prehuman beings. So the traditional doctrine of the fall needs to be reinterpreted.

While, on the other hand, Robert Wright says that 'the idea that John Stuart Mill [and many modern social scientists after him] ridiculed -of a corrupt human nature, of 'original sin'- doesn't deserve such summary dismissal" (Wright 1996,13). A tendency to sin, or to do evil, or to be selfish might be a fatal flaw in our nature that we cannot overcome by social engineering. Wright thinks that this is something that evolutionary psychology can confirm. Is this Christian idea then something that theories in evolutionary psychology can, at least to a limited extent, support? John T. Mullen thinks so. He argues that all but one of the versions of the doctrine of original sin that he identifies can "be rendered more epistemically probable upon the addition of evolutionary psychology to one's belief structure" (Mullen 2007, 269).

Hence there seems to be good reasons to embrace the contact view rather than the independent view. But how much contact there is between the two, depends on the concrete content of Christians' beliefs and of the scientific theories.

\section{The Competition View}

But what about the competition view, the idea that science and religion compete for the same job? Is there a way its advocates can respond to my argument so far? A fairly common reply would be to embrace scientism and maintain that only science can give us genuine (in contrast to apparent) knowledge about reality.

In the words of Bertrand Russell: "Whatever knowledge is attainable must be attained by scientific methods; and what science cannot discover, mankind cannot know" (Russell 1978:243). Or more recently Peter Atkins, in his argument for the limitless power of science, claims that: "There is no reason to suppose that science cannot deal with every aspect of existence. Only the religious -among whom I include not merely the prejudiced but also the underinformed-hope that there is a dark corner of the physical Universe, or of the universe of experience, that science can never hope to illuminate" (Atkins 1995, 125).

Since the only epistemic job (or job of obtaining knowledge) available is occupied by science, Christianity (or any other religion) cannot have such 
a job to fulfill. Science could perhaps not take over all jobs religion do, but in the cognitive realm there has been a competition and science is the winner. There is perhaps salvation, but no knowledge, to be found outside of science.

However, there are many problems with scientism (Stenmark 2001, 1833). (1) One problem that scientism faces is that science did not develop until around the seventeenth century. It is hard to say when exactly it began to emerge in its modern form, but science is certainly a newcomer in human history. So then, what about the people who lived before the development of the scientific method and the knowledge that this method (or rather cluster of methods) has generated since the seventeenth century? Did they not know anything at all? Scientism seems to entail that there would not have been any knowledge available before the dawn of science. Not until the discovery of the scientific method can human beings have known anything about themselves or the world around them. But is this standpoint a reasonable one?

I would maintain, to the contrary, that people living say 10000 years ago did know quite a lot about many things. Imagine a group of people sitting around the fire all those years ago in what we today call Africa. They knew that they had to eat to survive, that John (or whatever his name) was in love with Maria, that John's parents were dead and that there were, in the bushes nearby, dangerous animals that they should be careful to avoid. John knew that he was thinking about Bill, his brother, who was out hunting. They knew that you could trust some people but not others. They surely knew a lot of other things as well. It is true that, since the development of science, we know more than these earlier people did about the physical world, but my point is this: before the development of science there was human knowledge available, and therefore there is no good reason to believe that only science can give us knowledge. It also follows that, even if the scientific project had never gotten underway, we would still know many things.

(2) I shall further argue that knowledge about social reality is something that science cannot give us, and it is a kind of knowledge few of us would on reflection deny that we have. Let me give you an example of what I mean by knowledge of the social world. I am not talking about the social sciences, but merely about commonsense knowledge or everyday life knowledge. Suppose I go into a café in Stockholm and sit down on a chair at a table. The waiter comes and I utter a fragment of a sentence in Swedish. 
I say, "Kan jag få en öl, tack?" The waiter brings the beer and I drink it. I read a book and notice a Coca-Cola sign on the wall and cars outside the window. I leave some money on the table and leave. This sounds simple but, and this is the point, its significant features fall outside the scope of science. We cannot capture the features of the description I have just given in the language of physics and chemistry or any other of the natural sciences. There is no physical-chemical description adequate to define "café," "waiter," "sentence in Swedish," "money," or even "chair" and "table," even though cafés, waiters, money, chairs and tables are physical phenomena. Since no physical-chemical description can be given of these social phenomena, no scientific knowledge of the social world exists. But we do know these things; a large chunk of our knowledge is of the social world we inhabit! Where science only can see masses of metal in linear trajectories, we can see cars being driven along the road. Where science only can see cellulose fibers with green and grey stains, we can see dollar bills.

(3) Moreover, there are many things which we must know before we are able to conduct any science or are able to derive any scientific knowledge. This is because scientific knowledge depends upon other sources of knowledge. One example will have to suffice: memorial knowledge. I remember that I am married to Anna and fell in love with her in 1986, and that I have been talking about scientism today. Furthermore, I do not merely believe these things, I also reckon that I know these things. In fact I am more certain that these things are true than that the theory of evolution or the Big bang theory is true. But I do not think that the beliefs of memory can be scientifically established. Rather, to be able to develop and test a scientific hypothesis against a certain range of data, scientists have to be able to remember, for instance, the content of the hypothesis, the previous test results and, more fundamentally, that they are scientists and where their laboratories are located.

(4) The biggest problem with scientism, though, is that it undermines itself. Because what methods in for instance biology, chemistry, or physics are suitable to show that the proposition "the only genuine kind of knowledge we can have is scientific knowledge" is true? Well, hardly those methods that make it possible for scientists to discover and explain electrons, protons, genes, survival mechanisms, and natural selection. The reason is not that the content of this belief is too small, too distant or too far in the past for science to determine its truth-value (or probability); rather, it is that beliefs of this sort are not subject to scientific investigation. The belief 
that only science can give us knowledge about reality is a view in the theory of knowledge and is, therefore, an issue for philosophy and not a matter for science. But if it is an issue for philosophy we cannot know that the proposition "the only genuine kind of knowledge we can have is scientific knowledge" is true, because we would then have non-scientific knowledge. Hence scientism is self-refuting.

\section{The Contact View Exemplified}

So what about the contact view, is it the view Christians should adopt? I think so. The contact view, I would embrace, says that science and Christianity do different, but not completely different, jobs. They do different jobs because Christianity aims at reestablishing our broken relationship with God (soteriological goal) and, in the process, helps us to live a good life (moral goal), whereas science have neither of these goals. But they do not do completely different jobs because both attempt to say something true about reality (epistemic goal) and for this reason there could be some contact between the two.

Let me in more details give you one example where I think there is this kind of contact between Christianity and science. The issue concerns the Christian belief that there is something special or unique about human beings because they are the only creatures on the earth that are created in the image of God. We can call this the idea of human uniqueness and inevitability. And here we find both a challenge and an opportunity for Christians.

\section{Evolutionary Theory and the Christian Belief in Human Uniqueness and Inevitability}

The idea is roughly that Christians believe that God had certain intentions in mind when God decided to create this world. Part of God's plan with the creation was to create a certain kind of creatures, self-conscious creatures, that is, living things who could be aware of themselves, who would have freedom, be able to love and act morally and to obtain knowledge about God's creation and about God himself and enter into a relationship with God. In short, there is a reason why Homo sapiens are here.

But some biologists say things like this (and I will just quote Stephen Jay Gould but there are many other who have made similar claims): "Biology took away our status as paragons created in the image of God.... Before Darwin, we thought that a benevolent God had created us" (Gould 
1977: 267). Evolutionary biology has shown that "we are the accidental result of an unplanned process ... the fragile result of an enormous concatenation of improbabilities, not the predictable product of any definite process" (Gould 1983: 101-102). "Homo sapiens ... ranks as a 'thing so small' in a vast universe, a wildly improbable evolutionary event, and not the nub of universal purpose" (Gould 1999: 206). It is not quite clear how this argument should be stated, but let me anyhow suggest one way of developing these remarks into a more complete argument. I shall simply call the argument the "anti-human inevitability argument."

So the anti-human inevitability argument goes something like this:

1) The human species came into existence through the process of evolution.

2) But all individual species that come into existence through the process of evolution are random (that is, have a low probability) with respect to what evolutionary biologists can predict or retrospectively explain.

3) Something which is improbable and unpredictable cannot be planned by someone.

Therefore, the existence of the human species is not planned by God or anything like God.

(1), (2) and (3) are premises of this argument and then comes the conclusion of the argument.

But is the second premise really relevant? I would say that it is far from obvious. It seem to me that the relevant issue is not, strictly speaking, what is probable given the scientific information or theories we possess, but what is probable given what we could assume that God's knowledge would be about the outcome of the evolutionary process that science investigates, if certain initial conditions are initiated at the beginning of the universe.

So the relevant premise is rather:

2*) But all individual species that come into existence through the process of evolution are random (that is, have a low probability) with respect to what God can predict at the origin of the universe.

Now, Christians have different views about how extensive God's knowledge is but they certainly think it exceeds by far our knowledge, even 
the knowledge of our brilliant biologists. It means that God's possibility to predict with great accuracy the outcome of future natural causes and events is probably enormous. We cannot, therefore, automatically assume that what is likely given such amount of knowledge is the same as what is likely given the scientific knowledge that we happen to have.

So if God planned to create us and if it is likely that we would actually come into existence, given what God can know about the future of the evolving creation, then one could reasonably claim that we are here for a reason, and that there is a purpose in this sense to our existence. To establish the opposite conclusion seems to require more than basing one's calculation of probable outcomes on current scientific theories. At any rate, it follows that a successful version of the argument takes us far outside the domain of science and into philosophy and theology.

\section{Scientism Again}

But perhaps the unstated assumption is that science surely sets the limited of what we can know so this God talk is just irrelevant or nonsense. So maybe the argument should be stated in this way:

1) The human species came into existence through the process of evolution.

2) But all individual species that come into existence through the process of evolution are random (that is, have a low probability) with respect to what evolutionary biologists can predict or retrospectively explain.

3) Something which is improbable and unpredictable cannot be planned by someone.

4) The only things we can know anything about or rationally believe anything about are the ones science can discover.

Therefore, the existence of the human species is not planned by God or anything like God.

I have already talked about the problems with scientism but let me nevertheless repeat some of what I said earlier. The difficulty with such a revision of the argument is that the extra premise appears to contain a non-scientific claim. For how can one set up a scientific experiment to demonstrate the truth of premise (4)?

What methods in, for instance, biology or physics are suitable for such a task? Well, hardly those methods that make it possible for scientists to discover and explain electrons, protons, genes, mutations and natural selection. 
Furthermore it is not because the content of this belief is too small, too distant or too far in the past for science to determine its truth-value. Rather it is that beliefs of this sort are not subject to scientific inquiry. We cannot come to know (4) by appeal to science alone.

Premise (4) is rather a view in the theory of knowledge and is, therefore, a piece of philosophy and not a piece of science. But if it is a piece of philosophy then we cannot know it to be true because we would then have non-scientific knowledge, which the premise denies the possibility of. Thus, the more profound problem with the premise is that it seems to undermine itself. If it is true, then it is false.

So what we have here is a version of the anti-human inevitability argument, which contains a controversial non-scientific premise (scientism) and moreover appears to be self-refuting.

\section{Too Anthropocentric?}

But on the other hand why should Christians be so anthropocentric (or Homo-sapiens- centric)? Does it really matter what particular physical form the image of God would have? What Christians seem to be committed to believe is rather that central to God's purpose is, as Keith Ward puts it, the 'generation of communities of free, self-aware, self-directing sentient beings' (Ward 1996: 191).

On such an account the purpose of genes is to build bodies, the purpose of bodies is to build brains, and the purpose of brains is to generate consciousness and even self-consciousness, and with it there appears for the first time in natural history, reflective and critical thinking, experiences of meaning, love and forgiveness and a capacity to choose between good and evil. This development is something that was part of God's plan with creation, although the specific development of human beings was not part of that plan.

I suggest that Christians may as a response to what we have come to know through evolutionary biology about the development of life on earth, rethink their religious faith in such a way that they do not any longer think that the human race was planned by God. Instead of believing that God had a particular species in mind, they could believe that what God had in mind was the emergence of a generation of communities of free, self-aware, self-directing sentient beings.

The benefit of revising Christian beliefs in this way is that the likelihood that such a life form would appear in evolutionary history is, at least 
in the eyes of our scientists, much higher than that a particular instance of this type of life, Homo sapiens, would emerge. To quote a Nobel prize winner: The biochemist, Christian de Duve, writes:

Life was bound to arise under the prevailing conditions, and it will arise similarly wherever and whenever the same conditions obtain. There is hardly any room for "lucky accidents" in the gradual, multistep process whereby life originated.... I view this universe [as] ... made in such a way as to generate life and mind, bound to give birth to thinking beings (de Duve 1995: XV and xviii).

So there is the possibility of contact (and of fruitful dialogue) between science and Christianity, even though the aims of these two practices are quite different.

\section{Different Models of The Contact View}

So far I have made a distinction between three views (or paradigms) of how science and Christian faith are related:

1) The Competition view: Science and Christianity compete for the same job. They have the same aims but not necessarily the same means (or methods) to obtain their aims.

2) The Independent view: Science and Christianity do completely different jobs. They have completely different aims and means (or methods) to obtain their aims.

3) The Contact view: Science and Christianity do jobs that overlap to some extent. They have different but not completely different aims and means (or methods) to obtain their aims.

Many scholars (including theologians) who are engaged in the sciencereligion dialogue today think that some version of the contact paradigm is the view to hold. But they still come to radically different conclusions about these areas of contact between science and Christian faith. They, I would say, develop different models of the contact view. For instance, the biochemist Arthur Peacocke claims that those attempting to develop a Christian theology which takes into account contemporary science have been content to leave intact relatively traditional formulations of the Christian faith, but he think that we have to realize that there is a "need for radical revisions that are necessary if coherence and intellectual integrity are to be achieved" 
(Peacocke 2007,6). Former professor of mathematical physics and ordained priest John Polkinghorne, on the other hand, would argue that traditional formulations of the Christian faith can been left relatively intact (Polkinghorne 1998).

There are at least three issues involved here: (1) In the area of contact between science and Christian faith, do both need to change or just one of them? (2) How much do Christian faith and perhaps also science need to change? (3) Why do the advocates of the contact paradigm answer question (1) and (2) in so different ways? I suggest that we distinguish between four models of the contact view. They offer different answer to the first two questions and typically presuppose different answers to the third question.

According to the conservative $e^{1}$ contact model, it is primarily science that needs to change its content, whereas traditional Christianity is to a very large extent satisfactory as it is. Conservative Christians who are severely critical of evolutionary theory would exemplify this view, for instance, Johnson, Dembski and, to a lesser extent perhaps, the philosopher Plantinga. Alvin Plantinga argues that the theory of evolution is by no means religiously neutral and he is therefore ready to reject parts of it. Science needs to be reconciled with Christianity so that something we might call "theistic science" is born: "what we [Christians] need when we want to know how to think about the origin and development of contemporary life is what is most plausible from a Christian point of view" (Plantinga 199129 ).

According to the traditional contact model, science might need to change some of its content whereas Christianity certainly needs to change some but not most of its traditional content. Situated here, but perhaps positioned somewhat towards the previous model, would be Alister McGrath, professor of historical theology, and Nancey Murphy, professor of Christian philosophy, whereas Polkinghorne and Ward would be located further along towards the other end. Francis Collins would also be one of the advocates of this view. These scholars read the Bible much less literally than

\footnotetext{
${ }^{1}$ We could perhaps say that conservatives are those believers whose primary concern is to safeguard the religious tradition - to ensure that no perceived element of truth or of what is good and right in it is lost - and liberals are those who primarily want to do full justice to the perceived truth of modern thinking, scientific discoveries, and contemporary experience. Conservatives are afraid of losing something they already have, whereas liberals are afraid of missing something new. Radicals are those liberal believers who favor extreme changes in existing religious doctrines or traditions, whereas fundamentalists are those conservative believers who favor no change at all or as little change as possible in existing religious doctrines or traditions.
} 
the advocates of the conservative model and accept Biblical criticism without much question. They are not ready to privilege Christianity to the extent that the advocates of the previous model do, but neither do they privilege science to the extent that the proponents of the next model are typically willing to do. Polkinghorne's comment about such people is significant. He writes that there is in their thinking too high a degree of oneway assimilation and accommodation: "this stance will always carry the danger of the subordination of the theological to the scientific. It is theology that will tend to be assimilated into science" (Polkinghorne 1996, 7).

The third model is the liberal contact model. According to this model science is fine as it is; it is rather Christianity that needs to change most (but not all) of its traditional content. Peacocke illustrates this stance well when he writes that the aim of his work "is to rethink our 'religious' conceptualizations in the light of the perspectives on the world afforded by the sciences" (Peacocke 1993,3). Liberals, again roughly, read the Bible essentially symbolically, privilege science without question, and reject, or at least significantly modify, the traditional theistic notion of God. They instead want to embrace, for instance, panentheism or yet further "naturalize" the notion of God and to speak about theistic or religious naturalism, or alternatively to talk about an unknowable transcendent mystery named the 'Real' or the 'Ultimate.' To varying degrees, Barbour, Drees, Kaufman, Peacocke and systematic theologian Sallie McFague exemplify those scholars whose work assumes the liberal model. The elevated view of science presupposed in the model becomes explicit when, for instance, Ted Peters, professor of systematic theology, writes that science's 'ruthless dedication to empirically derived truth renders science brutal in its disregard for previous beliefs, even sacred beliefs' (Peters 2005, 8180). This is in sharp contrast to the nonprivileged perhaps even debunking view of science that we shall see exhibited in the next model.

There is also a fourth model worth exploring, although I would hesitate to identify names of scholars in the dialogue who would presuppose it in their writing. According to the postmodern or constructivist contact model, neither science nor (traditional or liberal) Christianity are acceptable as they are; rather, both need to change radically.

The starting point would be with radical postmodern literary theory and scholars such as Nietzsche, Derrida, Foucault, and Rorty, and with philosophers and sociologists of science such as Thomas Kuhn, Barry Barnes, David Bloor and Sandra Harding. Their ideas are then applied to the science-religion dialogue. What we are invited to understand is that both science and religion are social constructs developed to satisfy certain needs 
or interests. Consequently, the natural world has a small to non-existent role in the construction of scientific knowledge. Not only religious truth but also scientific truth is a reflection of power relations at a particular time. There is no objective truth to be found. In the words of Don Cupitt, a philosopher of religion: 'The world as such - if indeed we can speak of such a thing at all -is no more than a featureless flux of becoming, which different cultures simply order in different ways' (Cupitt 1986,133). When applied to science, this means that the universe has no inherent structure for scientists to task themselves to discover. All our stories about the world are just transient constructs, and a scientific or a religious perspective are just two among many. If we understand science and religion in this or a similar way it is quite possible to reconcile them with each other.

\section{The Relevance of EPISTemology}

Why do the advocates of the contact view answer question (1) and (2) in so different ways? I think that there are many reasons, but one reason has to do with differences in epistemology. I have in mind issues such as:

- What is it rational to believe and what can we know?

- How can we obtain rational beliefs and knowledge?

- How far do scientific methods reach?

- Are there subjects science is not competent to deal with?

- Is science more competent do deal with some subjects than others?

Some theologians, like Gordon Kaufman, are close to accepting scientism, that is to say they hold or presuppose in their theological thinking a scientistic view of knowledge: science alone can provide us with genuine knowledge (and perhaps also rational belief). But these theologians, nevertheless, think that Christian faith gives us symbols (but not beliefs), rituals and perhaps ethical guidelines we should not live without. Kaufman maintains that "as far as we know, personal agential beings did not exist, and could not have existed, before billions of years of cosmic evolution of a very specific sort and then further billions of years of biological evolution also of a very specific sort had transpired." How, then, he asks rhetorically, "can we today think of a person-like creator-God as existing before and apart from any such evolutionary developments?" (Kaufman 2001, 410). His argument seems to presuppose scientism. Why should theologians stop believing in a person-like creator-God? It is because science cannot support 
the existence of such a God and -this is what needs to be presupposed for the argument to be valid-since science alone gives us knowledge and rational belief, theologians should stop believing in a person-like creator-God. So the implicit acceptance of a scientistic view of knowledge and rational belief, would at least partially explain why someone like Kaufman advocates a very liberal contact model.

Other theologians are not ready accept scientism, but they still hold or assume, what we could call, a privileged view of scientific knowledge. Such an epistemology says that science provides us with the most reliable path to knowledge and rational belief. Willem B. Drees expresses this view when he writes that:

A relevant approach to naturalism in the context of "science and religion" is, in my opinion, to use it as a label for a world-view that follows the natural sciences as its major guide for understanding the world we live in and are a part of. Such a naturalism is not formally implied by the sciences, since other logically coherent constructions may be possible; but it is a view of the world that stays as close as possible to mainstream consolidated science when it articulates its ideas about the ontology and history of reality. (Drees 2006, 110)

Science should be our major guide to knowledge and rational belief. If you cannot scientifically justify a Christian belief, say in a personal God who created the world, maybe it is rational to accept it, but it could hardly be known to be true. Because this epistemological stance is adopted, Christian theology probably needs to go through major changes.

Others in the science-religion dialogue rather hold or assume a privileged view of Christian knowledge. So for instance Plantinga writes:

there is the Sensus Divinitatis, which is a source of belief in God, and the Internal Testimony of the Holy Spirit, which is the source of belief in the distinctive doctrines of Christianity. Beliefs produced by these sources go beyond reason in the sense that the source of their warrant is not the deliverances of reason; of course it does not follow that such beliefs are irrational, or contrary to reason ... On this view, religion and faith have a source of properly rational belief independent of reason and science; it would therefore be possible for religion and faith to correct as well as be corrected by science and reason. (Plantinga 2007)

Not only is it the case that Christians can know that many of their beliefs are true; they should also in at least some cases give them greater epistemic weight than they give to certain scientific truth claims. If one holds 
such a view then one is much more likely that one ends up advocating a conservative contact view.

Postmodern theologians are likely to see things quite differently, especially if they embrace a socially constructed view of knowledge. Knowledge is socially constructed, that is to say that knowledge -in science and religion-is constructed by society or groups with society in ways that reflect their particular social needs, interests or values. So on this view not only religious truth but also scientific truth is a reflection of power relations at a particular time. Kevin J. Vanhoozer writes in The Cambridge Companion to Postmodern Theology that "Truth on this view [postmodernism] is a compelling story told by persons in positions of power in order to perpetuate their way of seeing and organizing the natural and social world" (Vanhoozer 2003,11). So we have different truths which different groups of people embrace and know to be true, due to the compelling stories told by persons in position of power within these groups. But because these postmodern theologians ${ }^{2}$ do not think -due to the epistemology they acceptthat there is anything special about science (it is just another discourse), we seldom find them engaged in the science-religion dialogue ${ }^{3}$.

\section{References}

ATKINS, Peter, 1995. "The Limitless Power of Science," John Cornwell (ed), Nature's Imagination, Oxford: Oxford University Press.

CuPITT, Don, 1986. Lifelines, London: SCM Press.

DE Duve, Christian, 1995. Vital Dust: Life as a Cosmic Imperative, New York: Basic Books.

Drees, Willem B., 2006. "Religious Naturalism and Science," Philip Clayton (ed.), The Oxford Handbook of Religion and Science, Oxford: Oxford University Press.

Gould, Stephen Jay, 1977. Ever Since Darwin. London: Penguin Books. Gould, Stephen Jay, 1983. "Extemporaneous Comments on Evolutionary Hope and Realities", Charles L. Hamrum, red. Darwin's Legacy, Nobel Conference XVIII, San Franscisco: Harper \& Row.

\footnotetext{
${ }^{2}$ Notice, however, that not all theologians who see themselves as postmodernists hold this view of knowledge and truth. So a postmodern theologian, like Wentzel van Huyssteen, is very much engaged in the science-religion dialogue.

${ }^{3}$ I have developed these ideas more fully in my book How to Relate Science and Religion (Eerdmans, 2004).
} 
Gould, Stephen Jay. 1999. Rocks of Ages. New York: The Ballantine Publishing Group.

KaufMan, Gordon, 2001. "On Thinking of God as Serendipitous Creativity," Journal of the American Academy of Religion, 69.

MidGLEY, Mary, 1992. Science as Salvation. London: Routledge.

Mullen, John T. 2007. "Can Evolutionary Psychology Confirm Original Sin?" Faith and Philosophy 24.

Peacocke, Arthur, 1993. Theology for a Scientific Age, Minneapolis: Fortress Press.

PeAcocke, Arthur, 2001. Paths from Science towards God. Oxford: Oneworld.

PeAcocke, Arthur, 2007. 'A Naturalistic Christian Faith for the TwentyFirst Century,' Philip Clayton (ed.). All that Is, Minneapolis: Fortress Press.

Peters, Ted, 2005. 'Theology and Natural Science,' D. and F. Ford (eds). The Modern Theologians, Oxford: Blackwell.

Plantinga, Alvin, 1991. "When Faith and Reason Clash: Evolution and the Bible," Christian Scholar's Review, 21.

PlantingA, Alvin, 2007. "Religion and Science," Stanford Encyclopedia of Philosophy.

PolkingHORNE, John, 1996. Scientists as Theologians, London: SPCK.

POLKINGHORNE , John, 1998. Belief in God in an Age of Science, New Haven: Yale University Press.

Rolston, Holmes, 1999. Genes, Genesis and God. Cambridge: Cambridge University Press.

RusSELL, Bertrand, 1978 [1935]. Religion and Science, Oxford: Oxford University Press.

STENMARK, Mikael, 2001. Scientism: Science, Ethics and Religion. Aldershot: Ashgate.

STENMARK, Mikael, 2004. How to Relate Science and Religion, Grand Rapids: Eerdmans.

VAnHoozer, Kevin J. (ed.), 2003. The Cambridge Companion to Postmodern Theology, Cambridge: Cambridge University Press.

WRIGHT, Robert. 1996. The Moral Animal. London: Abacus.

WyKSTRA, Stephen. 1990. "Reasons, Redemption, and Realism," M. D. Beaty, ed. Christian Theism and the Problems of Philosophy. Notre Dame, Ind.: University of Notre Dame Press. 